\title{
Inactivation of Escherichia coli in Water by Combined Process of Silver Nanoparticle and Ultraviolet Radiation
}

\author{
Mohammad Ali Zazouli, ${ }^{1}$ Maryam Yousefi,, ${ }^{2, *}$ Yousef Kor, ${ }^{3}$ and Mitra Roohafzaee ${ }^{2}$ \\ ${ }^{1}$ Department of Environmental Health Engineering, Health Sciences Research Center, Faculty of Health, Mazandaran University of Medical Sciences, Sari, IR Iran \\ ${ }^{2}$ Department of Environmental Health Engineering, Student Research Committee, Mazandaran University of Medical Sciences, Sari, IR Iran \\ ${ }^{3}$ Department of Water and Wastewater engineering, Gomishan Health Center, Golestan University of Medical Sciences, Gorgan, IR Iran \\ "Corresponding author: Maryam Yousefi, Department of Environmental Health Engineering, Student Research Committee, Mazandaran University of Medical Sciences, Sari, IR \\ Iran. Tel: +98-9119029780, E-mail: Maryam_u3fi7@yahoo.com
}

Received 2016 July 01; Revised 2016 September 16; Accepted 2016 September 21.

\begin{abstract}
Background: Now the goal of water disinfection is not just inactivation of pathogenic organisms, but other goals such reduction or minimization of disinfection by products (DBPs) formation, providing residue to control secondary infections, maintaining the disinfectant's residue in the water distribution system to take care of public health are important too.

Objectives: The current study aimed to study the effectiveness of new technologies such as combined process of silver nanoparticles (AgNPs) with ultraviolet (UV) radiation on Escherichia coli inactivation as a water microbial pollution index and effects of some parameters on its efficiency.

Methods: AgNPs with average diameter of $20 \mathrm{~nm}$ was used in the presence or absence of UV light for disinfection. Escherichia coli species were cultured according to the standard methods for water and wastewater examination. The results were reported as CFU/mL.

Results: Results showed that the disinfection efficiency of the UV light and silver nanoparticles (UV + AgNPs) combined process was more than that of the catalyst AgNP. The maximum efficiencies of the three processes of UV, AgNPs and UV + AgNPs in 60 minutes were $66 \%, 89 \%$ and $99 \%$, respectively. The efficiency decreased with increasing the colony densities. However, statistical least significant difference (LSD) test showed no significant impact on the two consecutive levels $(P>0.05)$. The removal efficiency increased with increasing the catalyst dose and contact time. The removal efficiency reached $100 \%$ when the catalyst dose was $0.4 \mathrm{mg} / \mathrm{L}$ at 20 minutes contact time.

Conclusions: It was concluded that the efficiency of silver nanoparticles to remove E. coli increases under the UV light. Intensified disinfection practice was due to producing electrons, active holes and active radicals by irradiation of UV light on AgNPs.
\end{abstract}

Keywords: Combined Process, Silver Nanoparticles, UV Radiation, Water Disinfection, Escherichia coli

\section{Background}

Disinfection is the most important stage in water treatment to prevent waterborne diseases and ensure that the water is free of pathogenic microorganisms $(1,2)$.

Some waterborne diseases and health risks include intestinal worms, cholera, typhoid, trachoma, schistosomiasis, diarrhea and legionellosis (3). So far, various chemical disinfection methods such as chlorination are widely used (4). This method is inexpensive, has low operating cost in a wide range of $\mathrm{pH}$ and adequate residual effect (5-7). Nevertheless, the main disadvantages of chlorination are the reaction with natural organic matter (NOM) and formation of disinfection by products (DBPs). The importance of DBPs includes trihalomethanes (THMs), haloacetic acids (HAA5) and other dissolved organic halogens. If these products are formed after disinfection, they have health risks especially potential human carcinogens even at low concentrations $(8,9)$. Already more than 500 DBPs are recognized in finished drinking water. The type and quantity of DBP depends on the oxidizing agents used as disinfectants and reaction conditions (10). It was reported that the prolonged consumption of DBPs with low concentration such as trihalomethanes ( $80 \mathrm{ppb}$ ) and haloacetic acid (60 ppb) might make connate cardiac defects (11). For these reasons, scientists attempt to find disinfection technologies that DBPs do not form the least quantity (1).

Ozonation after chlorination greatly promoted the disinfection performance for all pathogens such as viruses, bacteria and parasites as well as removing toxicity and mutagenicity caused to enhance water quality. However, ozonation was restricted due to potentially microorganism regrowth in water distribution networks and high cost of production and operation of ozonation (8).

Consequently, selecting a suitable disinfectant depends on technical dependability, economic and environmental criteria. Many problems involved in water quality could be obviated or greatly improved using products 
and processes resulting from the progression of nanotechnology and engineering processes (12). In recent years, nanoparticles were focused on a wide range of research areas, especially environmental issues (13).

Nanosilver has antimicrobial properties. It is the most widely product in disinfection processes (14). Three possible disinfection mechanisms of nanosilver are as follows: Bonding of nanoparticles to the outer bacterial cell to alter the function of membrane properties. The nanoparticles have a small size and high specific surface area. These properties will result in a strong contact between nanoparticles and the microorganism surface; DNA damage of bacteria after penetration of nanosilver into the bacterial cell; $\mathrm{Ag}^{+}$ ions release due to dissolution of nanosilver which can interact with sulfur-containing proteins in the bacterial cell wall, which may cause to lose its functionality. This mechanism is often considered as the main mechanism of the antimicrobial activity of nanosilver (15). Also, UV irradiation improved nanosilver inactivation of bacteria, since silver ions are active in the presence of UV irradiation.

Although the antibacterial mechanisms of nanoparticles are somewhat known (16-22), there are still questions about their effectiveness in destroying pathogens and the possibility of their use for water disinfection.

\section{Objectives}

The current study aimed to determine the effectiveness of a new technology such as combined process of silver nanoparticles and UV light on E. coli inactivation as a water microbial pollution index and effects of some parameters on its efficiency.

\section{Methods}

\subsection{Materials}

The catalyst employed in this work was silver nanoparticles (metal basis with $20 \mathrm{~nm}$ primary particle size, purchased from USNano Inc.). Escherichia coli ATCC 25922 (PTCC 1399) were purchased from Persian type culture collection company. All reagents were of analytical grade and were used without further purification. Tryptic soy agar (TSA), tryptic soy broth (TSB), barium chloride and sulfuric acid were supplied by MERC Germany. A 6 WUV-C lamp was provided from ARDA Inc. (France).

\subsection{Cell culture, Medium Preparation and Bacterial Counting}

Escherichia coli species were cultured according to the manufacturer guidelines. Briefly, a single colony of E. coli was taken from refrigerated stock and precultured in 20 $\mathrm{mL}$ TSB by incubation at $37^{\circ} \mathrm{C}$ for 24 hours. Then it was transferred into TSA and incubated for 24 hours at $37^{\circ} \mathrm{C}$. The top of each colony was touched with a sterile loop and the growth was transferred into a tube containing 4 to $5 \mathrm{~mL}$ of distilled water (23). A McFarland standard 0.5 was used to determine the cell concentrations. The cell density was compared to that of 0.5 McFarland standards using UV/VIS spectrophotometer; an equivalent optical density of 0.1 at $620 \mathrm{~nm}$ with regard to the calibrated standard cell suspensions in distilled water (24). Barium sulfate turbidity standard was used to standardize the inoculums density for a susceptibility test, its turbidity was equivalent to that of a 0.5 McFarland standards. A 0.5 McFarland standard was made according to Garcia (25).

To obtain the required cell suspensions, the stock was serially diluted in distilled water. This resulted in a suspension containing approximately $10^{3}, 10^{4}$ and $10^{5} \mathrm{CFU} / \mathrm{mL}$. The standard plating method was applied to confirm the bacterial concentrations. This test was done in triplicates on tryptic soy agar. Samples were plated in triplicate. The colonies were visually identified and counted after incubation at $37^{\circ} \mathrm{C}$ overnight.

\subsection{Experimental Procedure}

Disinfection experiments were carried out in distilled water. In all instances, glassware was cleaned with distilled water and finally autoclaved. To disperse the AgNPs uniformly in solution, it was suspended in water by presonication for 30 minutes. The characteristics of silver nanoparticles were determined by scanning electron $\mathrm{mi}$ croscope (SEM), transmission electron microscopy (TEM) and X-ray powder diffraction (XRD) analysis. A $6 \mathrm{~W}$ UV-C lamp was installed $5 \mathrm{~cm}$ above the samples surface. The length of the lamp was $30 \mathrm{~cm}$. The maximum emission of lamp was $254 \mathrm{~nm}$. The light intensity was measured by a radiometer at 200 to $400 \mathrm{~nm}$ (Hagner ECL-X) and the intensity was $1.8 \mathrm{w} / \mathrm{m}^{2}$. All samples were analyzed according to the standard methods for water and wastewater examinations (26).

The sterile $250 \mathrm{~mL}$ beakers were used as the photochemical cells. The magnetic stirrers were used to stir the samples. Schematic of the used reactors are illustrated in Figure 1. All experiments were done at $20^{\circ} \mathrm{C}$. In the first stage, the beakers containing $200 \mathrm{~mL}$ of polluted water were contacted with UV light, nanosilver and their combination. In the examinations studied various parameters such as E. coli concentration $\left(10^{3}, 10^{4}, 10^{5} \mathrm{CFU} / \mathrm{mL}\right)$, amount of $\operatorname{AgNPs}(0.05,0.1,0.2$ and $0.4 \mathrm{mg} / \mathrm{L})$ and time $(10,20,40$ and 60 minutes).

\subsection{Statistical Tests}

The normality of the data was assessed by KolmogorovSmirnov test. Amounts greater than 0.05 were considered 
Figure 1. Schematic Illustration of Reactor

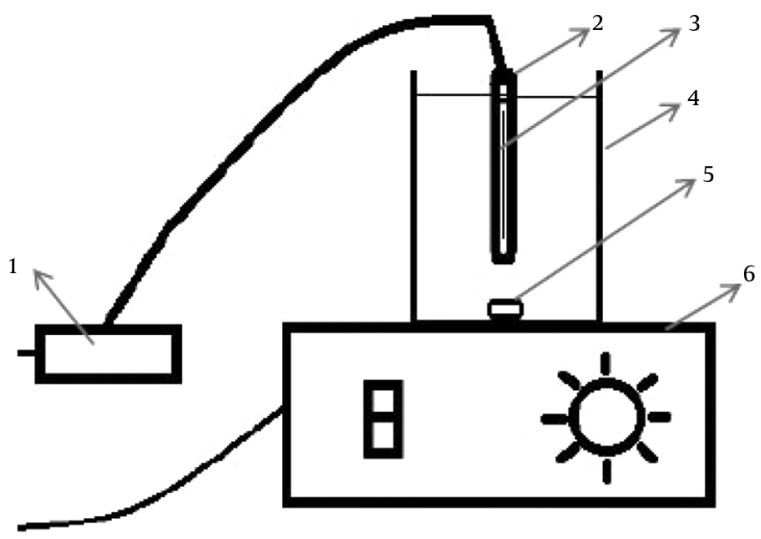

1, Transformator; 2, Quartz cover; 3, A 6 W UV lamp; 4, Reactor; 5, Magnet; 6, Magnetic stirrers.

as normal data. Then, T-test and ANOVA parametric tests were used for statistical analysis.

\section{Results}

\subsection{Nanoparticles Characteristics}

Silver nanoparticles were characterized by SEM, TEM and XRD analysis (Figure 2). Silver nanoparticles had a purity of 99.99\%, particle size of $20 \mathrm{~nm}$, the surface area of 18 - $22 \mathrm{~m}^{2} / \mathrm{g}$, density of $10.5 \mathrm{~g} / \mathrm{cm}^{3}$ and black color.

As can be observed in XRD analysis, the reflection angle was $2 \theta$ that confirmed the presence of silver nanoparticles. Also, the TEM images showed that the particles were well dispersed and spherical in shape. The particle size was 20 nm.

\subsection{The Kolmogorov-Smirnov Test}

To assess the normality of the data, KolmogorovSmirnov test was used. The results of the test showed that the data were normal $(\mathrm{P}>0.05)$. Therefore, parametric tests (T-test and ANOVA) were used. Results of the normality test showed $\mathrm{P}>0.05$, indicating data were normal. Hence, ANOVA was used.

\subsection{Effect of UVIrradiation on the Efficiency of AgNPS}

Three series of processes were carried out to perform this experiment. In all of the three experiments a fixed number of colonies per milliliter $\left(10^{5}\right)$ was used. In the first experiment, the bacteria were exposed to UV light without AgNPs. In the second experiment, the samples were exposed to the AgNPs without UV light. In the third experiment, samples were exposed both to the UV light and AgNPs. A silver nanoparticles concentration of $0.1 \mathrm{mg} / \mathrm{L}$ was used. The efficiency of disinfection in all experiments was determined in 10, 20, 40 and 60 minutes. The $\mathrm{pH}$ was adjusted at neutral range $(7.5 \pm 0.5)$ in all experiments. The efficiencies of bacterial inactivation at different times are illustrated in Figure 3A. As shown in this illustration, the efficiency of UV light was lower than that of AgNPs. Also the combined process (UV + AgNPs) was more effective than only UV light and only AgNP.

To ensure that the bacteria population without the presence of light and nanoparticles was changing over time or not, blank sample similar to the real sample was investigated and no changes were observed in the number of bacteria. Due to the lack of inactivation of bacteria, blank sample was not presented in the chart. As shown in Figure $3 A$, inactivation of E. coli by AgNPs increased in the presence of UV light. This finding indicated that maximum efficiencies in 60 minutes of UV, AgNPs and UV + nAg were $66 \%, 89 \%$ and $99 \%$, respectively.

\subsection{Effect of Bacterial Population}

The UV light and silver nanoparticles combined process (UV + AgNPs) was performed with different bacterial concentrations $\left(10^{3}, 10^{4}\right.$ and $\left.10^{5} \mathrm{CFU} / \mathrm{mL}\right)$ to study the effect of bacterial population on inactivation efficiency. The $\mathrm{pH}$ was adjusted at neutral range $(7.5 \pm 0.5)$ in all experiments. The contact time was 10, 20, 40 and 60 minutes. Figure 3B shows the effect of initial bacterial population on the inactivation efficiency of $E$. coli under optimum conditions. The silver nanoparticles dosage was $0.2 \mathrm{mg} / \mathrm{L}$ in these experiments. As shown in Figure 3B, inactivation efficiency was $100 \%$ when bacterial populations were lower than $10^{5}$ $\mathrm{CFU} / \mathrm{mL}$.

The results indicated that the inactivation efficiency decreased with increasing the number of colonies. An increase in the bacterial density decreases the chance of exposure to light and AgNPs. Therefore, researchers preferred to continue the experiments with the high number of colonies in such an order that methods could be comparable.

\subsection{Effect of Nanosliver Dosage}

Experiments were carried out with various silver nanoparticles dosage $(0.05,0.1,0.2$ and $0.4 \mathrm{mg} / \mathrm{L})$ to investigate the effect of AgNPs dosage on the inactivation efficiency of the UV light and silver nanoparticles (UV + AgNPs) combined process. The number of colonies was $10^{4}$ 

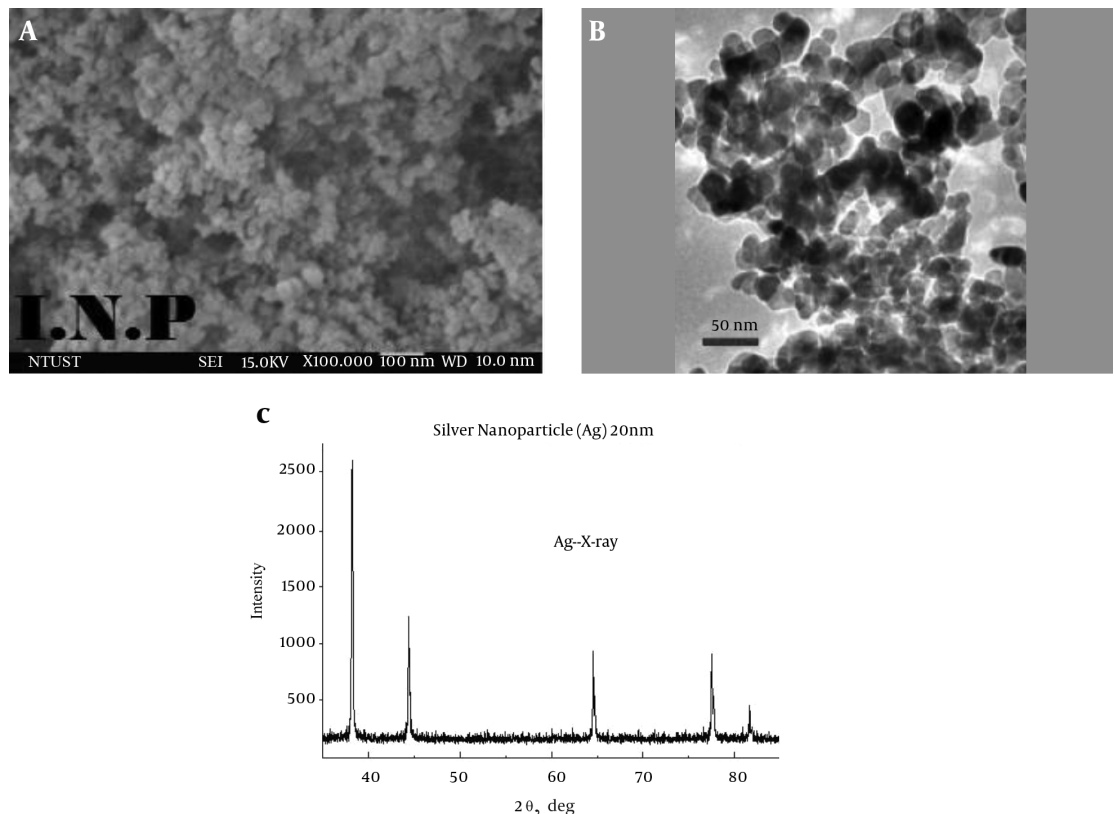

Figure 2. a, Scanning electron microscope; b, Transmission electron microscope and; c, X-ray diffraction of the AgNPs.

A

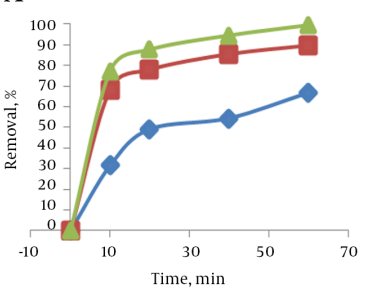

C

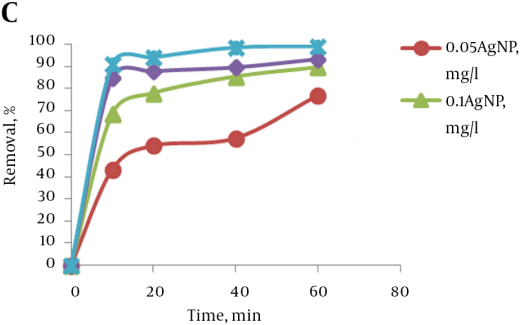

B

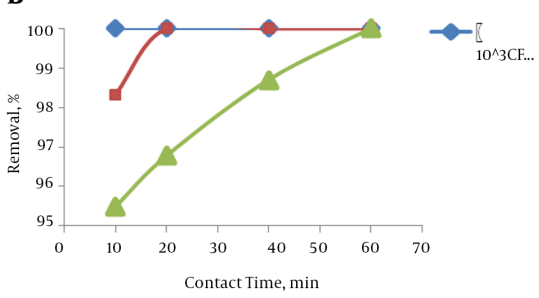

D

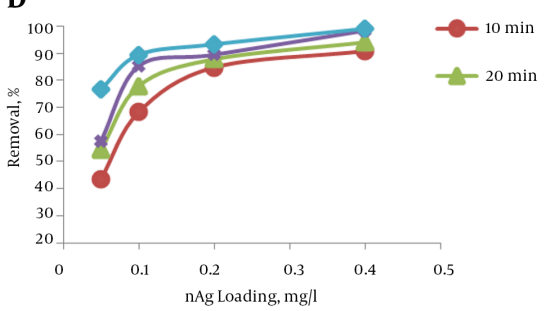

Figure 3. a, The effect of AgNPs and UV light on the E. coli inactivation efficiency (initial bacterial population: $10^{5} \mathrm{CFU} / \mathrm{mL}$ ); b, The effect of initial bacterial population on the combined process (UV+AgNPs), inactivation efficiency of E. coli (AgNPs dosage: $0.2 \mathrm{mg} / \mathrm{L}$ ); c, The effect of AgNPs dosage on the E. coli inactivation efficiency by the UV light and silver nanoparticles (UV + AgNPs) process (initial bacterial population: $10^{5} \mathrm{CFU} / \mathrm{mL}$ ) and; d, The effect of contact time on the $E$. coli inactivation efficiency by the UV light and silver nanoparticles (UV + AgNPs) process (initial bacterial population: $10^{5} \mathrm{CFU} / \mathrm{mL}$ )

$\mathrm{CFU} / \mathrm{mL}$ in these experiments. The results of the experiments are presented in Table 1. According to this tabulation, the inactivation efficiency of processes was $100 \%$, when the AgNPs dosage was more than $0.05 \mathrm{mg} / \mathrm{L}$. Even after 40 minutes, the inactivation efficiency of bacterial was $100 \%$ with $0.05 \mathrm{mg} / \mathrm{L}$ AgNPs dosage. Therefore, other exper- iments were performed with more number of colonies.

The comparison of the effect of different dosages of silver nanoparticles on disinfection efficiency was shown in Figure 3C. The minimum, average, and maximum efficiency of the combined processes with different dosages of AgNPs were presented in Table 2. According to this tabula- 
Table 1. The Effect of Nanosilver Dosage on the Efficiency of Ultraviolet Light and Silver Nanoparticles process

\begin{tabular}{|c|c|c|c|c|c|c|}
\hline \multirow[t]{2}{*}{ Number of Test } & \multirow[t]{2}{*}{ Initial Bacterial Population, $\times$ CFU $/ \mathbf{m L}$} & \multirow{2}{*}{$\begin{array}{c}\text { Silver } \\
\text { Nanoparticles Dosage, } \mathrm{mg} / \mathrm{L}\end{array}$} & \multicolumn{4}{|c|}{ Time, Min ${ }^{\mathrm{a}}$} \\
\hline & & & 10 & 20 & 40 & 60 \\
\hline $\mathbf{1}$ & 18 & 0.05 & 50 & 83.33 & 94.4 & 100 \\
\hline 2 & 18 & 0.1 & 89.9 & 100 & 100 & 100 \\
\hline 3 & 18 & 0.2 & 96.67 & 100 & 100 & 100 \\
\hline 4 & 18 & 0.4 & 100 & 100 & 100 & 100 \\
\hline
\end{tabular}

${ }^{\mathrm{a}}$ Values are expressed as percentages.

tion, the minimum and maximum of efficiency with 0.05 $\mathrm{mg} / \mathrm{L}$ of AgNPs dosage were $42 \%$ and $82 \%$, respectively. But its comparison with UV light process without catalyst was insignificant $(\mathrm{P}>0.05)$. By increasing the contact time and AgNPs dosage, minimum, average and maximum of efficiency ascends. Efficiency was $100 \%$, when the AgNPs dosage and time were $0.4 \mathrm{mg} / \mathrm{L}$ and 20 minutes, respectively.

\subsection{Effect of Time}

The effect of contact time $(10,20,40$ and 60 minutes) on UV + AgNPs process efficiency is shown in Figure 3D. According to this tabulation, inactivation efficiency increased by increasing the contact time.

\section{Discussion}

\subsection{Effect of UVIrradiation on the Efficiency of AgNPS}

The current study showed that the combined process (UV + AgNPs) was more effective than only UV light and only AgNP. The result of the study corresponded with the data given by Noroozi et al. (27) and Zazouli et al. (28); although they used $\mathrm{ZnO}$ and $\mathrm{TiO}_{2}$ nanoparticles, respectively.

Inactivation of E. coli with AgNPs increased in the presence of UV light. The nanoscale particles had a high specific relative surface area; therefore, their contact with bacteria increased and oxidation efficiency immensely improved $(13,29)$.

In the current study, by increasing the contact time from 10 to 60 minutes, the inactivation of bacteria increased. Therefore, in the presence of UV light and AgNPs, inactivation efficiency increased from $77 \%$ in 10 minutes to $99.31 \%$ in 60 minutes. Although inactivation efficiency increased by increasing the time, this trend was not very high after 20 minutes. Miranzadeh et al. (19) investigated the effect of silver nanoparticles on the coliforms removal and water disinfection and showed that while increasing the time in all concentrations, the removal of probable coliforms ascended. Their results were in accordance with the findings of the current study.

Miranzadeh et al. (19) showed that after $100 \mathrm{~min}$ utes contact in the $0.06 \mathrm{mg} / \mathrm{L}$ silver concentration, the maximum removal efficiency was observed (92.41\%). Also, ANOVA test showed that a significant relationship between time and E. coli removal. Noroozi et al. (27) studied the photocatalytic removal of E. coli by ZnO. They reported that the efficiency of UV light, ZnO and UV/ZnO processes to inactivate $1000 \mathrm{CFU} / \mathrm{mL}$ of $E$. coli was $70 \%, 90 \%$ and $100 \%$, respectively. Whereas in the current study, the maximum efficiency of UV light process to inactivate $E$. coli was $66 \%$. The reason for this difference was the number of bacteria. The number of bacteria in the current study was $10^{5} / \mathrm{mL}$, but in that of Noroozi et al. (27) was $10^{3} / \mathrm{mL}$.

The comparison of the effect of UV light process, AgNPs, and UV light and silver nanoparticles combined process (UV + AgNPs) showed that the removal efficiency of UV light process was lower than that of AgNPs; and those of the two of them individually were lower than that of combined process. The study on the effect of three processes by LSD test (95\% Confidence intervals) showed that the effects of UV light as compared with those of AgNPs and UV + AgNPs were significant $(\mathrm{P}<0.05)$, but the comparison of AgNPs process with $U V+$ AgNPs process was insignificant $(P$ $>0.05)$. However, disinfection efficiency of combined process (UV + AgNPs) was more than that of only the catalyst (AgNPs). This efficiency difference was about 9\% -10\% in all times.

\subsection{Effect of Bacterial Population}

The results indicated that the inactivation efficiency decreased with increasing the number of colonies. But statistical LSD test showed that their effect was insignificant in two consecutive concentrations ( $\mathrm{P}>0.05)$. However, disinfection efficiency with $10^{5} \mathrm{CFU} / \mathrm{mL}$ E. coli was lower than $10^{4} \mathrm{CFU} / \mathrm{mL}$ and $10^{3} \mathrm{CFU} / \mathrm{mL}$. Disinfection efficiency was $100 \%$ when bacterial population was $10^{4} \mathrm{CFU} / \mathrm{mL}$ and 
Table 2. The Effect of Silver Nanoparticles Dosages on the E. coli Inactivation Efficiency by the Ultraviolet Light and Silver Nanoparticles Process ${ }^{\mathrm{a}}$

\begin{tabular}{|c|c|c|c|c|c|c|c|c|c|c|c|c|c|}
\hline \multirow[t]{3}{*}{ Number of Test } & \multirow[t]{3}{*}{ Silver Nanoparticles Dosage, $\mathrm{mg} / \mathrm{L}$} & \multicolumn{12}{|c|}{ Contact Time, Min } \\
\hline & & \multicolumn{3}{|c|}{10} & \multicolumn{3}{|c|}{20} & \multicolumn{3}{|c|}{40} & \multicolumn{3}{|c|}{60} \\
\hline & & Min & Mean \pm SD & Max & Min & Mean \pm SD & Max & Min & Mean \pm SD & Max & Min & Mean \pm SD & Max \\
\hline 1 & 0.05 & 42.4 & $43.2 \pm 0.9$ & 44.2 & 52.4 & $54.2 \pm 1.8$ & 56 & 55.2 & $57.5 \pm 2.4$ & 60 & 64.8 & $76.8 \pm 11$ & 86.2 \\
\hline 2 & 0.1 & 52 & $68.2 \pm 14$ & 77.2 & 66 & $77.9 \pm 11$ & 87.6 & 68 & $85.3 \pm 15$ & 94.4 & 70.4 & $89.5 \pm 16.5$ & 99.3 \\
\hline 3 & 0.2 & 60.8 & $84.7 \pm 21$ & 97.9 & 68 & $87.8 \pm 11$ & 98.6 & 70.8 & $89.6 \pm 16.3$ & 99.3 & 80 & $93.3 \pm 11.5$ & 100 \\
\hline 4 & 0.4 & 76.8 & $90.7 \pm 12.1$ & 98.6 & 82.8 & $94.1 \pm 9.7$ & 100 & 95.6 & $98.5 \pm 2.5$ & 100 & 97.2 & $99.1 \pm 1.6$ & 100 \\
\hline
\end{tabular}

$10^{3} \mathrm{CFU} / \mathrm{mL}$. The effect of bacterial population was significant only between $10^{3} \mathrm{CFU} / \mathrm{mL}$ and $10^{5} \mathrm{CFU} / \mathrm{mL}(\mathrm{P}<0.05)$.

The antimicrobial properties of silver compounds and ions were identified many years ago, and were applied to disinfect medical devices, home appliances, and water treatment. But the mechanism of toxicity is still only partially understood. Interaction of silver ions with thiol groups present in proteins, result in inactivation of respiratory enzymes and lead to the creation of reactive oxygen species (ROS). Also, Ag ions inhibit DNA replication and affect the structure of cell membrane and alter its permeability. Moreover, the use of silver ions and UV irradiation together promote inactivation of bacteria and viruses. It is presumed that a combination of Ag and cysteine promotes photodimerization of viral genome contributing to a synergistic effect observed in inactivation of Haemophilus influenzae and MS2 phages (30).

Already, several mechanisms are assumed for the antimicrobial properties of nanosilver: Bonding to the cell surface that leads to altering the functions of the cell membrane properties. It is reported that silver nanoparticles can degrade lipopolysaccharide molecules, accumulate inside the membrane by forming pits, and increase membrane permeability; silver nanoparticles can penetrate into the bacteria cell, and then damage DNA of bacteria; Ag ions are released by dissolution of AgNPs. The antimicrobial activity of AgNPs depends on their physicochemical properties. In other words, physicochemical properties have an important role in antimicrobial activity. Generally, particles that their size is less than $10 \mathrm{~nm}$ are more toxic to bacteria such as E. coli and Pseudomonas aeruginosa (30).

\subsection{Effect of Nanosliver Dosage}

Statistical analysis showed that the efficiency of combined process with $0.05 \mathrm{mg} / \mathrm{L}$ of catalyst was not significant, as compared with only UV light process ( $\mathrm{P}>0.05$ ), but was significant when more catalyst dosage was used $(\mathrm{P}<0.05)$. The contact with bacteria increased; hence, the efficiency increased. The differences between efficiency of combined process with 0.1 and $0.2 \mathrm{mg} / \mathrm{L}$ of catalyst were not significant. However, by increasing AgNPs dosage, the inactivation rate of bacteria increased. By increasing the AgNPs dosage, the probability of attachment of nanoparticles to the surface of bacteria, changing its membrane properties, its penetration into the cell and DNA damage and inactivation increase.

Rabbani et al. (31) investigated the disinfection of synthetic polluted water with 30 to $180 \mathrm{mg} / \mathrm{L}$ of nanosliver without UV light. They showed that by disinfection of water with 30 to $180 \mathrm{mg} / \mathrm{L}$ of nanosilver without UV irradiation, the further coliforms were removed when the concentration of AgNPs was raised, which corresponded with the results of the current study. But they reported no significant correlation between the AgNPs dosage and coliform removal $(P=0.6)$. However, statistical analysis showed that this relation was significant in the current study.

The effect of nanoparticles on bacteria removal was studied by Gao et al. (18). They reported that regardless of the time, LC50 of nanosilver against the E. coli and Ceriodaphnia dubia was lower than 112.14 and 6.18, respectively. However, in this study, $0.1 \mathrm{mg} / \mathrm{L}$ of nanosilver with $10 \mathrm{~min}$ utes contact time caused the inactivation of $52 \%$ of $E$. coli species.

\subsection{Effect of Time}

The current study showed that the inactivation efficiency increased by increasing the contact time. Rabbani et al. (31) showed that by increasing the contact time, the inactivation efficiency increased in all concentrations of AgNPs. Statistical analysis showed that the efficiency of combined process with $0.05 \mathrm{mg} / \mathrm{L}$ of silver nanoparticles was significant $(\mathrm{P}<0.05)$ in different times, as compared with those of UV light process. Only between 20 and 40 minutes was not significant $(\mathrm{P}>0.05)$. Also it was not significant at more concentration of AgNPs ( $P>0.05)$. The maximum activity of nanoparticles occurred at $0.05 \mathrm{mg} / \mathrm{L}$ concentration and 60 minutes contact time, but based on statistical tests, it was not significant in more dosages. However, it had a rising trend. While the contact time in- 
creases, the contact of nanoparticles and bacteria, its penetration into cells, the rate of silver ions production and then the rate of bacterial inactivation increase (15).

\subsection{Conclusion}

The current study aimed to evaluate the efficiency of the UV light and silver nanoparticles (UV + AgNPs) process in water disinfection. The final results of this study were summarized as follows:

1, The efficiency of the UV + AgNPs process was more than that of only AgNPs catalyst. In fact UV irradiation had a synergistic effect on efficiency of AgNPs. The difference of efficiencies was about $9 \%-10 \%$ at various times; 2 , The minimum, median and maximum inactivation efficiency increased by increasing AgNPs dosage and contact time. As the minimum, median and maximum efficiency at dosage of $0.4 \mathrm{mg} / \mathrm{L}$ of AgNPs and contact time of 20 minutes were $82.8,94.1 \pm 9.7$ and $100 \%$, respectively; 3 , The statistical test showed that the efficiency of the UV+AgNPs process at 0.05 $\mathrm{mg} / \mathrm{L}$ dosage of AgNPs compared with that of UV light only was insignificantly different $(\mathrm{P}>0.05)$. But it was significant $(\mathrm{P}<0.05)$, when more AgNPs dosage was used. The increase of dosage increased the rate of photoexcitition and radical production. Furthermore, its contact with bacteria and also efficiency increased; 4, While bacterial population increased, the photocatalytic process efficiency decreased. When the bacterial population increased, the contact with light and catalyst and also photocatalytic products decreased.

Finally, it is suggested to evaluate the disinfection efficiency of nanosilver in form of composite or coated on specific materials and zeolites, the comparison between combined process with silver nanoparticles and silver ions, and disinfection process with nanocatalyst compared with non-nanocatalyst. Also there is a need for similar studies on inactivation of microorganisms such as heterotrophic plate count (HPC) bacteria, total coliforms and fecal coliforms and fecal streptococci.

\section{Acknowledgments}

The authors would like to acknowledge their gratitude to the research and operation group of rural water and wastewater company, Golestan province, Iran, for funding this research project. Also authors appreciate faculty of health, Mazandaran University of Medical Sciences for their support. The authors wish to thank Dr. Dianati and Mrs, Eslamifar for their collaboration on this project.

\section{Footnotes}

Authors' Contribution: The overall implementation of this study including design, experiments, data analysis and manuscript preparation were the results of joint efforts by individuals who are listed as co-authors of this paper. All authors have made extensive contribution into the review and finalization of this manuscript. All authors read and approved the final manuscript.

Funding/Support: This study was supported by the rural water and wastewater company, Golestan province, Iran (project No. 91/1920).

\section{References}

1. Chong M, Jin B, Saint C. Bacterial inactivation kinetics of a photodisinfection system using novel titania-impregnated kaolinite photocatalyst. Chem Eng J. 2011;171(1):16-23.

2. Gholami M, Mirzaei R, Mohammadi R, Zarghampour Z, Afshari A. Destruction of Escherichia coli and Enterococcus faecalis using low frequency ultrasound technology: a response surface methodology. Health Scope. 2014;3(1).

3. Niven R. Investigation of silver electrochemistry water disinfection applications. McGill; 2005.

4. Salvato JA, Nemerow NL, Agardy FJ. Environmental engineering. John Wiley and Sons; 2003.

5. Agency EP. Water Treatment Manual:Disinfection. $2011: 187$.

6. Huang J, Wang L, Ren N, Ma F, Ju L, Liu X. Disinfection effect of chlorine dioxide on viruses, algae and animal planktons in water. Envi Chem. 1995;15(4):347-55.

7. Junli H, Li W, Nenqi R, Li L, Fun SR, Guanle Y. Disinfection effect of chlorine dioxide on viruses, algae and animal planktons in water. Water Res. 1997;31(3):455-60.

8. Sun DD, Tay JH, Tan KM. Photocatalytic degradation of E. coliform in water. Water Res. 2003;37(14):3452-62. doi: 10.1016/S00431354(03)00228-8. [PubMed: 12834738].

9. Lin S, Huang R, Cheng Y, Liu J, Lau BL, Wiesner MR. Silver nanoparticlealginate composite beads for point-of-use drinking water disinfection. Water Res. 2013;47(12):3959-65. doi:10.1016/j.watres.2012.09.005. [PubMed: 23036278].

10. Richardson SD. New disinfection by-product issues: emerging DBPs and alternative routes of exposure. Global Nest J. 2005;7(1):43-60.

11. Coleman HM, Marquis CP, Scott JA, Chin SS, Amal R. Bactericidal effects of titanium dioxide-based photocatalysts. Chem Engin J. 2005;113(1):55-63.

12. Savage N, Diallo MS. Nanomaterials and water purification: opportunities and challenges. J Nanoparticle Res. 2005;7(4-5):331-42.

13. Nakata K, Fujishima A. Photocatalysis: Design and applications. JPhotochem Photobiol C: Photochem Rev. 2012;13(3):169-89.

14. Bondarenko O, Juganson K, Ivask A, Kasemets K, Mortimer M, Kahru A. Toxicity of Ag, CuO and $\mathrm{ZnO}$ nanoparticles to selected environmentally relevant test organisms and mammalian cells in vitro: a critical review. Arch Toxicol. 2013;87(7):1181-200. doi: 10.1007/s00204-013-10794. [PubMed: 23728526].

15. Reidy B, Haase A, Luch A, Dawson KA, Lynch I. Mechanisms of silver nanoparticle release, transformation and toxicity: a critical review of current knowledge and recommendations for future studies and applications. Materials. 2013;6(6):2295-350.

16. Morones JR, Elechiguerra JL, Camacho A, Holt K, Kouri JB, Ramirez JT, et al. The bactericidal effect of silver nanoparticles. Nanotechnology. 2005;16(10):2346-53. doi: 10.1088/0957-4484/16/10/059. [PubMed: 20818017]. 
17. Tugulea AM, Berube D, Giddings M, Lemieux F, Hnatiw J, Priem J, et al. Nano-silver in drinking water and drinking water sources: stability and influences on disinfection by-product formation. Environ Sci Pollut Res Int. 2014;21(20):11823-31. doi: 10.1007/s11356-014-2508-5. [PubMed: 24458938].

18. Gao J, Youn S, Hovsepyan A, Llaneza VL, Wang Y, Bitton G, et al. Dispersion and toxicity of selected manufactured nanomaterials in natural river water samples: effects of water chemical composition. Environ Sci Technol. 2009;43(9):3322-8. [PubMed: 19534153].

19. Miranzadeh MB, Rabbani D, Naseri S, Nabizadeh R, Mousavi SGA, Ghadami F. Coliform bacteria removal from contaminated water using nanosilver. Feyz J Kashan Univ Med Sci. 2012;16(1).

20. Li Y, Zhang W, Niu J, Chen Y. Mechanism of photogenerated reactive oxygen species and correlation with the antibacterial properties of engineered metal-oxide nanoparticles. ACS Nano. 2012;6(6):5164-73. doi: 10.1021/nn300934k. [PubMed: 22587225].

21. Xie Y, He Y, Irwin PL, Jin T, Shi X. Antibacterial activity and mechanism of action of zinc oxide nanoparticles against Campylobacter jejuni. Appl Environ Microbiol. 2011;77(7):2325-31. doi: 10.1128/AEM.0214910. [PubMed: 21296935].

22. Radzig MA, Nadtochenko VA, Koksharova OA, Kiwi J, Lipasova VA, Khmel IA. Antibacterial effects of silver nanoparticles on gramnegative bacteria: influence on the growth and biofilms formation, mechanisms of action. Colloids Surf B Biointerfaces. 2013;102:300-6. doi:10.1016/j.colsurfb.2012.07.039. [PubMed: 23006569].
23. IROST . Persian Type Culture Collection 2016. Available from: http:// ptcc.irost.org/en/index.asp? code $=1$.

24. Dhara L, Tripathi A. Antimicrobial activity of eugenol and cinnamaldehyde against extended spectrum beta lactamase producing enterobacteriaceae by in vitro and molecular docking analysis. Eur $J$ Integrative Med. 2013;5(6):527-36.

25. Garcia L. Preparation of Routine Media and Reagents Used in Antimicrobial Susceptibility Testing. ASM; 2010.

26. Apha A. WPCF, Standard methods for the examination of water and wastewater. American public health association, American water works association, water environment federation; 1995.

27. Noroozi R, Mehdinezhad MH. Photocatalytic removal of Escherichia coli by $\mathrm{ZnO}$ activated by ultraviolet-C light from aqueous solution. Med Laborat J. 2011;5(2):52-61.

28. Zazouli M, Ahanjan M, Kor Y, Eslamifar M, Hosseini M, Yousefi M. Water disinfection using Photocatalytic process with titanium dioxide Nanoparticles. J Mazandaran Univ Med Sci. 2015;24(122):227-38.

29. Reisner DE. Bionanotechnology II: Global Prospects. 2. CRC Press; 2011

30. Li Q, Mahendra S, Lyon DY, Brunet L, Liga MV, Li D, et al. Antimicrobial nanomaterials for water disinfection and microbial control: potential applications and implications. Water Res. 2008;42(18):4591-602. doi: 10.1016/j.watres.2008.08.015. [PubMed: 18804836].

31. Rabbani D, Miranzadeh MB, Ghadami F, Zarjam R. Effect of nanosilver solution on coliforms removal in synthetic polluted water. $J$ Appl Technol Environ Sanit. 2013;3(1). 